\title{
Biomineralization of hydrous Mg carbonates and silicates
}

\author{
C. LAMÉRAND*1,2 ${ }^{*}$ L.S. SHIROKOVA ${ }^{1}$, P. BÉNÉZETH ${ }^{1}$, \\ J-L. ROLS ${ }^{2}$, O.S. POKROVSKY ${ }^{1}$ \\ ${ }^{1}$ Université de Toulouse; UPS; GET (Geosciences and \\ Environment Toulouse) UMR 5563 CNRS; 14 Avenue \\ Edouard Belin, 31400 Toulouse, France \\ (*correspondence : celine.lamerand@get.omp.eu) \\ ${ }^{2}$ Université de Toulouse; INP; UPS; EcoLab (Laboratoire \\ Ecologie Fonctionnelle et Environnement); 118 Route de \\ Narbonne, 31062 Toulouse, France
}

The biomineralization of $\mathrm{CO}_{2}$ in the form of carbonate minerals is considered as one of the efficient solutions of atmospheric $\mathrm{CO}_{2}$ removal, allowing stable and sustainable storage of this greenhouse gas. The weathering of (ultra)mafic rocks such as olivine, first step of $\mathrm{CO}_{2}$ storage, releases small amounts of $\mathrm{Si}$ in the environment, which could impact the formation of secondary $\mathrm{Mg}$ carbonates and allow the formation of silicate minerals. Although the formation of carbonate rocks by cyanobacteria in the form of stromatolites has been well documented (e.g., [1], [2], [3]), the effect of dissolved $\mathrm{Si}$ on kinetics of precipitation and the nature of formed solid phases have not been yet studied.

In this work, we studied, via laboratory experiments, the biologically-induced precipitation of hydrous $\mathrm{Mg}$ carbonates and silicates from carbonate-bearing medium enriched in $\mathrm{Mg}$ and in presence of a small amount of Si $(\sim 0.3 \mathrm{mM})$ in the presence of cyanobacteria Synechococcus sp., in order to characterize the rates, stoichiometry and mineralogical nature of precipitates.

Our results demonstrated the formation of $\mathrm{Mg}$ carbonates and silicates via the increase of $\mathrm{pH}$ induced by the photosynthetic activity of cyanobacteria. Transmission electron microscopy observations and associated chemical and crystallographic analyzes identified magnesium carbonates around the cells which could be nesquehonite $\left(\mathrm{MgCO}_{3} \cdot 3 \mathrm{H}_{2} \mathrm{O}\right) \quad$ and/or hydromagnesite $\left(\mathrm{Mg}_{5}\left(\mathrm{CO}_{3}\right)_{4}(\mathrm{OH})_{2} \cdot 4\left(\mathrm{H}_{2} \mathrm{O}\right)\right.$, as well as an amorphous $\mathrm{Mg}$ silicate, sepiolite $\left(\mathrm{Mg}_{4} \mathrm{Si}_{6} \mathrm{O}_{15}(\mathrm{OH})_{2} \cdot 6 \mathrm{H}_{2} \mathrm{O}\right)$. Overall, the presence of $\mathrm{Si}$ allowed the formation of sepiolite but did not prevent the formation of $\mathrm{Mg}$ carbonates.

[1] Mavromatis et al. (2012), Geochim. Cosmochim. Acta 76, 161-174. [2] Shirokova et al. (2013), Aquat. Geochem. 19, 1-24. [3] Martinez et al. (2016), Appl. Geochem. 75, 7689. 